\title{
Leptin and leptin receptors in the prostate and seminal vesicles of the adult rat
}

\author{
WITOLD MALENDOWICZ ${ }^{1}$, MARCIN RUCINSKI ${ }^{2}$, CARLO MACCHI $^{3}$, RAFFAELLA SPINAZZI ${ }^{3}$, \\ AGNIESZKA ZIOLKOWSKA ${ }^{2}$, GASTONE G. NUSSDORFER ${ }^{3}$ and ZBIGNIEW KWIAS ${ }^{1}$
}

\begin{abstract}
Departments of ${ }^{1}$ Urology and ${ }^{2}$ Histology and Embryology, Poznan University of Medical Sciences, PL-60781 Poznan, Poland; ${ }^{3}$ Department of Human Anatomy and Physiology, Section of Anatomy, University of Padua, I-35121 Padua, Italy
\end{abstract}

Received March 16, 2006; Accepted May 27, 2006

\begin{abstract}
Leptin is an adipose tissue-secreted hormone that acts via specific receptors (Ob-R), of which six isoforms are at present recognized (from Ob-Ra to Ob-Rf). Ob-Rb is the only isoform able to activate JAK-STAT and MAPK signaling cascades. A large body of evidence suggests that leptin and its receptors are involved in prostate physiology and pathophysiology in humans, but studies on the leptin system in the rat prostate are lacking. Reverse transcription-polymerase chain reaction showed the expression of mRNAs of leptin, $\mathrm{Ob}-\mathrm{Ra}, \mathrm{Ob}-\mathrm{Rb}, \mathrm{Ob}-\mathrm{Rc}, \mathrm{Ob}-\mathrm{Re}$ and $\mathrm{Ob}-\mathrm{Rf}$ in adult rat seminal vesicles and prostate (coagulating, dorsal, ventral and lateral lobes). Western blotting demonstrated the presence in these specimens of the $\mathrm{Ob}-\mathrm{Rb}$ protein, and immunocytochemistry revealed that $\mathrm{Ob}-\mathrm{Rb}$ was mainly located in their epithelial-cell component. Collectively, these findings strongly suggest that leptin and $\mathrm{Ob}-\mathrm{R}$ may be involved in the autocrine-paracrine functional regulation of the epithelial cells of adult rat seminal vesicles and prostate.
\end{abstract}

\section{Introduction}

Leptin is an adipose tissue-secreted hormone, which decreases caloric intake and increases energy expenditure (reviewed in ref. 1). Subsequent studies showed that leptin is also involved in the regulation of angiogenesis, hematopoiesis and neuroendocrine functions (2-6), as well as in the stimulation of the proliferative activity of various cell types both in vivo and in vitro (7-9).

Leptin exerts its biological effects through the activation of specific receptors $(\mathrm{Ob}-\mathrm{R})$, of which six isoforms are at present recognized (from $\mathrm{Ob}-\mathrm{Ra}$ to $\mathrm{Ob}-\mathrm{Rf}$ ). All $\mathrm{Ob}-\mathrm{R}$ isoforms share a common extracellular ligand-binding domain, but only five of them (Ob-Ra, Ob-Rb, Ob-Rc, Ob-Rd and Ob-Rf)

Correspondence to: Professor G.G. Nussdorfer, Department of Human Anatomy and Physiology, Section of Anatomy, Via Gabelli 65, I-35121 Padua, Italy

E-mail: gastone.nusdorfer@unipd.it

Key words: leptin, leptin receptors, seminal vesicles, prostate, rat contain an intracellular domain. Of these isoforms only Ob-Rb contains all intracellular parts able to activate either JAK-STAT (Janus kinase-signal transducer and activator of transcription) or MAPK (mitogen-activated protein kinase) signaling pathways. Ob-Re does not contain transmembrane and intracellular domains, and circulates as a soluble receptor $(2,5,10-15)$.

Data are available showing that leptin and $\mathrm{Ob}-\mathrm{R}$ are expressed in the human prostate (16), but similar studies have not been performed in the rat. Hence, we examined the expression of leptin and its receptor isoforms in rat prostate and seminal vesicles by reverse transcription (RT)-polymerase chain reaction (PCR), Western blotting and immunocytochemistry (ICC).

\section{Materials and methods}

Animals and reagents. Male adult Wistar rats, bred in our laboratory facilities, were kept on a 14:10-h light:dark cycle (illumination onset at 8:00 am) at $23^{\circ} \mathrm{C}$, with free access to laboratory pellets and tap water. Animals were decapitated, and their prostates with seminal vesicles were promptly removed. The study protocol was approved by the local Ethics Committee for Animal Studies. Rabbit polyclonal anti-mouse $\mathrm{Ob}-\mathrm{Rb}$ primary antibody was purchased from Alpha Diagnostic International (San Antonio, TX), and peroxidase-conjugated anti-rabbit IgG secondary antibody was from Dako (Glostrup, Denmark). Bovine serum albumin (BSA), phosphate buffered saline (BSA) and all other chemicals and laboratory reagents were provided by Sigma-Aldrich Corp. (St. Louis, MO).

$R T-P C R$. Total RNA was extracted from frozen prostate and seminal vesicle specimens, as previously detailed $(17,18)$, and contaminating DNA was eliminated by DNase I treatment (RNase-Free DNase set; Promega, Madison, WI). The amount of total RNA was determined (19), and RT was performed using AMV reverse transcriptase (Promega) with Oligo dT (PE Biosystems, Warrington, UK) as primers. PCR was carried out as described previously $(20,21)$, using glyceraldehyde-3phosphate dehydrogenase (GAPDH) as a housekeeping reference gene, and the following amplification program: denaturation step $\left(95^{\circ} \mathrm{C}\right.$ for $\left.10 \mathrm{~min}\right)$, and 35 cycles of threestep amplification (denaturation, $95^{\circ} \mathrm{C}$ for $10 \mathrm{sec}$; annealing, $58^{\circ} \mathrm{C}$ for $5 \mathrm{sec}$; and extension, $72^{\circ} \mathrm{C}$ for $10 \mathrm{sec}$ ). The primer sequence and the predicted size of the PCR products are shown 
Table I. PCR primers and PCR products.

\begin{tabular}{|c|c|c|c|}
\hline Primer & Sequence $\left(5^{\prime}-3^{\prime}\right)$ & Product size (bp) & Accession number \\
\hline \multicolumn{4}{|l|}{ Leptin $(\mathrm{Ob})$} \\
\hline Sense (190-209) & GAC ATT TCA CAC ACG CAG TC & & \\
\hline Antisense (366-384) & GAG GAG GTC TCG CAG GTT & 195 & NM013076 \\
\hline \multicolumn{4}{|l|}{$\mathrm{Ob}-\mathrm{Ra}$} \\
\hline Sense (110-131) & CAC TGT TAA TTT CAC ACC AGA G & & \\
\hline Antisense (323-344) & GTC ATT CAA ACC ATA GTT TAG G & 235 & AF304191 \\
\hline \multicolumn{4}{|l|}{$\mathrm{Ob}-\mathrm{Rb}$} \\
\hline Sense (2635-2653) & TGC TCG GAA CAC TGT TAA T & & \\
\hline Antisense (2785-2805) & GAA GAA GAG CAA ATA TCA & 171 & U52966 \\
\hline \multicolumn{4}{|l|}{$\mathrm{Ob}-\mathrm{Rc}$} \\
\hline Sense $(35-53)$ & TGC TCG GAA CAC TGT TAA T & & \\
\hline Antisense (172-195) & ATA GAG TAT CTA ACC TGC ACC CTT & 161 & AF007818 \\
\hline \multicolumn{4}{|l|}{ Ob-Re } \\
\hline Sense (595-614) & TCC TGG ACA CTG TCA CCT AA & & \\
\hline Antisense (759-778) & ATC AGG ATT GCC AAT TTA CA & 184 & AF007819 \\
\hline \multicolumn{4}{|l|}{ Ob-Rf } \\
\hline Sense (2676-2696) & GCTGCTCGGAACACTGTTAAT & & \\
\hline Antisense (2806-2826) & ACGGCATCCACTCTATATCCT & 151 & D84125 \\
\hline \multicolumn{4}{|l|}{ GAPDH } \\
\hline Sense $(18-37)$ & TTC TAG AGA CAG CCG CAT CT & & \\
\hline Antisense (104-123) & TGG TAA CCA GGT GTC CGA TA & 106 & X02231 \\
\hline
\end{tabular}
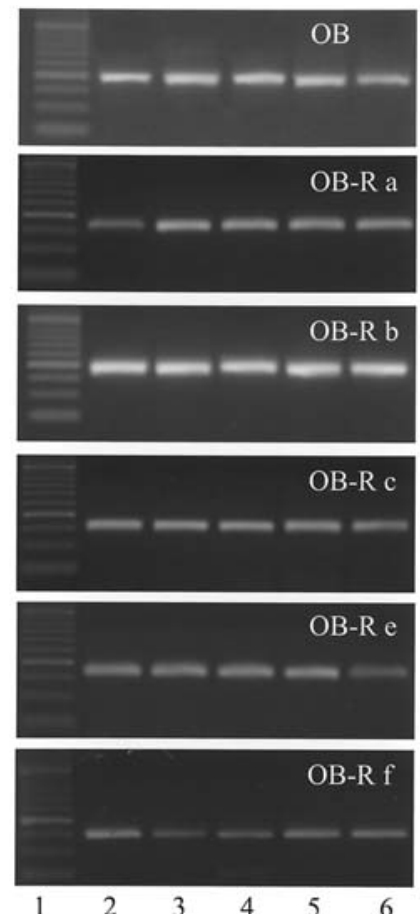

Figure 1. Ethidium bromide-stained $2 \%$ agarose gel showing cDNA amplified with rat leptin $(\mathrm{Ob})$ and $\mathrm{Ob}-\mathrm{R}$ specific primers from seminal vesicles (2), and coagulating (3), dorsal (4), ventral (5) and lateral (6) prostate lobes of an exemplary adult rat. Lane 1 was loaded with Roche Marker VIII (Roche, Mannheim, Germany). in Table I. Detection of the PCR amplicons was performed by size fractionation on $2 \%$ agarose gel electrophoresis. To rule out the possibility of amplifying genomic DNA, in some experiments PCR was carried out without prior RT of the RNA.

Western blotting. Prostate and seminal vesicle samples were homogeneized in Tris-sucrose-EDTA buffer (10 mM Tris, $250 \mathrm{mM}$ sucrose, and $0.1 \mathrm{mM}$ EDTA; $\mathrm{pH} 7.4$ ) and centrifuged at $600 \mathrm{x} \mathrm{g}$ for $30 \mathrm{~min}$ at $4^{\circ} \mathrm{C}$. Protein concentration was determined by the Bradford method, and Western blotting was carried out as previously detailed $(8,22)$. Briefly, $25 \mu \mathrm{g}$ of proteins for each sample were loaded into each lane, separated on an SDS (16\% sodium dodecyl sulphate)-polyacrylamide electrophoretic gel, and then transferred onto a PVDF membrane (Millipore, Bedford, MA). Non-specific binding was blocked by immersing the membrane in $5 \% \mathrm{BSA}$ at $4^{\circ} \mathrm{C}$ overnight. The membrane was then incubated for $120 \mathrm{~min}$ with the primary rabbit polyclonal anti Ob-Rb antibody $(1: 1000$ dilution). After washing in TBST (10 mM Tris, $150 \mathrm{mM} \mathrm{NaCl}$ and $0.05 \%$ Tween-20; $\mathrm{pH} 8.0$ ), membranes were incubated for $60 \mathrm{~min}$ at room temperature with peroxidase-conjugated anti-rabbit secondary antibodies (1:2500 dilution). The membranes were washed for $60 \mathrm{~min}$ in TBST, and immunoreactive bands were detected using the chemiluminescent luminol reagent (Amersham Life Science, Little Chalfont, UK). 


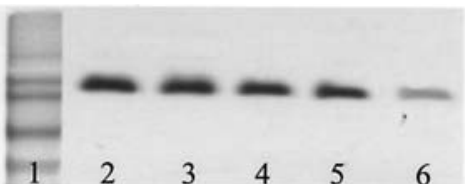

Figure 2. Western blot analysis of $\mathrm{Ob}-\mathrm{Rb}$ in protein extracts from seminal vesicles (2), and coagulating (3), dorsal (4), ventral (5) and lateral (6) prostate lobes of an exemplary adult rat. Lane 1 shows molecular mass standard (Santa Cruz Biotechnology, Santa Cruz, CA).

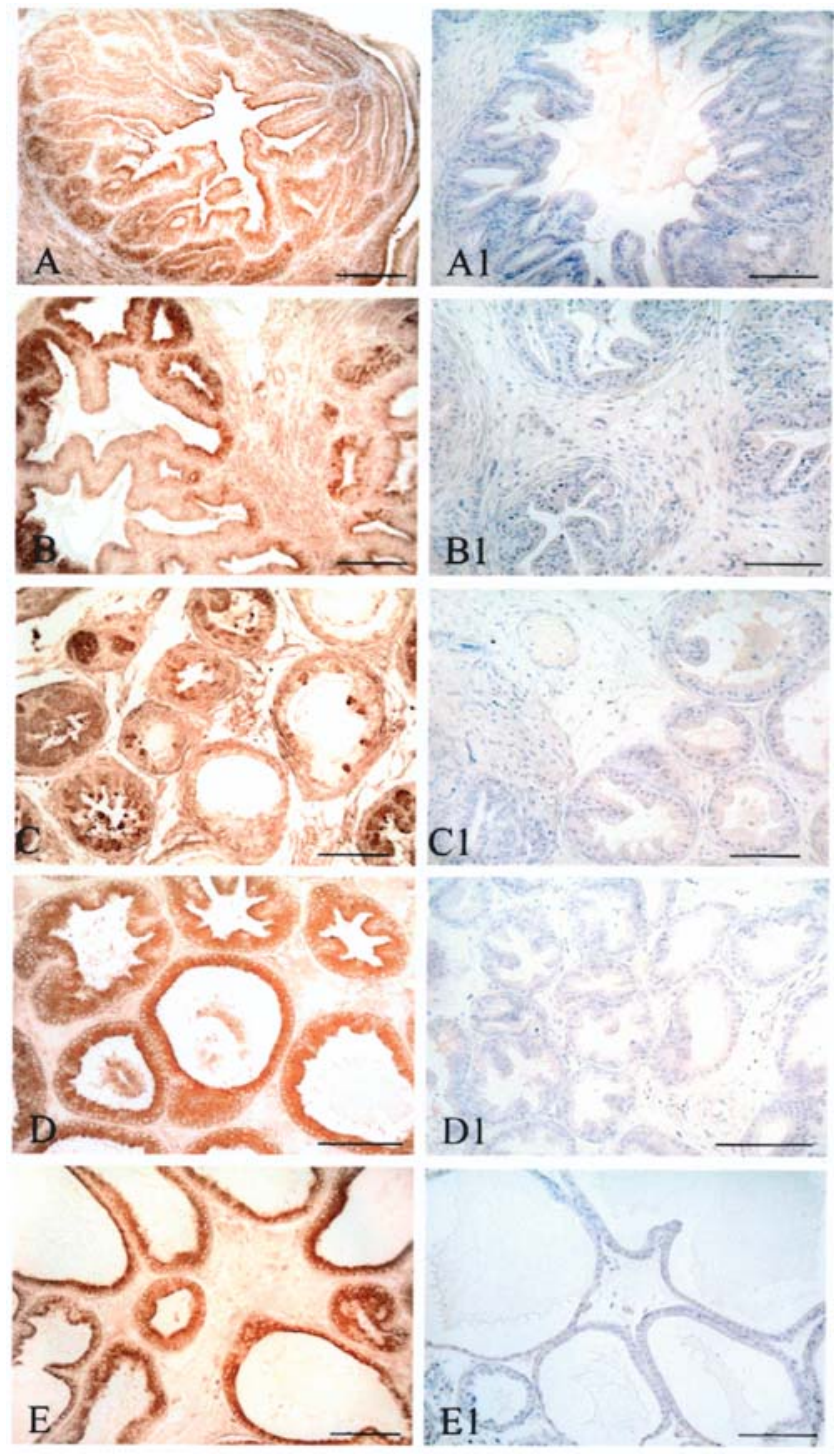

Figure 3. Immunocytochemical demonstration of $\mathrm{Ob}-\mathrm{Rb}$ in seminal vesicles (A), and coagulating (B), dorsal (C), ventral (D) and lateral (E) prostate lobes of an exemplary adult rat. The respective negative controls (A1-E1), obtained by omitting the primary antibody, are counterstained with hematoxylin. Bars: A and A1, $1 \mathrm{~mm}$; B-B1 to E-E1, $100 \mu \mathrm{m}$.

ICC. Prostate and seminal vesicle samples were fixed in Bouin's solution for $24 \mathrm{~h}$, embedded in paraffin and sectioned at $6 \mu \mathrm{m}$ of thickness. Sections were then deparaffinized, rehydrated and incubated in $1 \% \mathrm{H}_{2} \mathrm{O}_{2}$ for $30 \mathrm{~min}$ at room temperature to block endogenous peroxidase activity. After washing in PBS, sections were preincubated with normal goat serum for $30 \mathrm{~min}$, and then incubated with the primary rabbit polyclonal anti-Ob-Rb antibody (1:1000 dilution) for 120 min. After washing in PBS, sections were incubated for 60 min with peroxidase-conjugated anti-rabbit secondary antibodies (1:500 dilution), and peroxidase activity was detected using the Dako liquid DAB-substrate-chromogen system. Negative controls were carried out by similarly treating adjacent sections and omitting the primary antibody $(23,24)$.

\section{Results}

RT-PCR showed the expression of leptin and Ob-R isoforms (a,b,c,e and f) mRNAs in the seminal vesicles, and coagulating, dorsal, ventral and lateral lobes of the prostate of all rats studied (Fig. 1). Western blotting revealed the presence of $\mathrm{Ob}-\mathrm{Rb}$ protein in all specimens (Fig. 2), and ICC demonstrated that $\mathrm{Ob}-\mathrm{Rb}$ is mainly located on the epithelial cells (Fig. 3).

\section{Discussion}

The present PCR study demonstrated that leptin and its receptor mRNA are expressed in the rat seminal vesicles and prostate. Moreover, the presence of the fully active and JAKSTAT/MAPK-activating Ob-Rb isoform (5) protein has been documented by Western blotting, and ICC revealed its primary localization on the epithelial cells. Collectively, these findings strongly suggest that the leptin system may be involved in the autocrine-paracrine functional regulation of the epithelial cells of the adult rat prostate and seminal vesicles. The identification of free leptin in the human seminal plasma appears to be in keeping with this contention (25).

An increasing body of evidence suggests the involvement of leptin in human prostate growth and the development of prostate cancer, a strong correlation existing between the volume of body fat (i.e. obesity) and prostate cancer progression and mortality (26-29). Although obesity and leptin may not necessarily increase the risk of prostate cancer, they seem to promote it once established (30) and to favor the development of its more aggressive forms (31). The presence of Ob-Rs has been demonstrated not only in the normal human prostate (16), but also in prostate cancer (32) and prostate cancer-derived cell lines (PC-3 and DU-154) (33). Moreover, leptin has been found to stimulate the proliferation $(26,29,33,34)$, migration and growth-factor secretion of these cell lines (26), leading to the suggestion that the local intraprostatic leptin system may be involved in the development of prostate cancer in humans. Our present results may add support to this appealing hypothesis.

\section{Acknowledgements}

This study was in partial fulfillment of Ph.D by W.M. Thesis requirement of the School of Medicine, Poznan University of Medical Sciences.

\section{References}

1. Zhang Y, Proenca R, Maffei M, Barone M, Leopold L and Friedman JM: Positional cloning of the mouse obese gene and its human homologue. Nature 372: 425-432, 1994; erratum in Nature 374: 479, 1995. 
2. Ahima RS, Saper CB, Flier JS and Elmquist JK: Leptin regulation of neuroendocrine system. Front Neuroendocrinol 21: 263-307, 2000.

3. Ingvartsen KL and Boisclair YR: Leptin and the regulation of food intake, energy homeostasis and immunity with special focus on periparturient ruminants. Domest Anim Endocrinol 21: 215-250, 2001

4. Bates SH and Myers MG Jr: The role of leptin receptor signaling in feeding and neuroendocrine function. Trends Endocrinol Metab 14: 447-452, 2003.

5. Myers MG Jr: Leptin receptor signaling and the regulation of mammalian physiology. Recent Prog Horm Res 59: 287-304, 2004.

6. Zhang Y, Chen Y, Heiman M and Dimarchi R: Leptin: structure, function and biology. Vitam Horm 71: 345-372, 2005.

7. Li L, Mamputu JC, Wiernsperger N and Renier G: Signaling pathways involved in human vascular smooth muscle cell proliferation and matrix metalloproteinase-2 expression induced by leptin: inhibitory effect of metformin. Diabetes 54: 2227-2234, 2005.

8. Markowska A, Belloni AS, Rucinski M, Parenti AR, Nardelli GB, Drews K, Nussdorfer GG and Malendowicz LK: Leptin and leptin receptor expression in the myometrium and uterine myomas: Is leptin involved in tumor development? Int J Oncol 27: 1505-1509, 2005.

9. Sukhotnik I, Vadasz Z, Coran AG, Lurie M, Shiloni E, Hatoum OA and Mogilner JG: Effect of leptin on intestinal re-growth following massive small bowel resection in rat. Pediatr Surg Int 22: 9-15, 2006.

10. Tartaglia LA, Dembski M, Weng X, Deng N, Culpepper J, Devos R, Richards GJ, Campfield LA, Clark FT, Deeds J, Muir C, Sanker S, Moriarty A, Moore KJ, Smutko JS, Mays GG, Wool EA, Monroe CA and Tepper RI: Identification and expression cloning of a leptin receptor, OB-R. Cell 83: 1263-1271, 1995.

11. Bjorbaek C, Uotani S, Da Silva B and Flier JS: Divergent signaling capacities of the long and short isoform of the leptin receptor. J Biol Chem 272: 32686-32695, 1997.

12. Murakami T, Yamashita T, Iida M, Kuwajima M and Shima K: A short form of leptin receptor performs signal transduction. Biochem Biophys Res Commun 231: 26-29, 1997

13. Tartaglia LA: The leptin receptor. J Biol Chem 272: 6093-6096, 1997.

14. Friedman JM and Halaas JL: Leptin and the regulation of body weight in mammals. Nature 395: 763-770, 1998.

15. Yamashita T, Murakami T, Otani S, Kuwajima M and Shima K: Leptin receptor signal transduction: OBRa and OBRb of fa type. Biochem Biophys Res Commun 246: 752-759, 1998.

16. Cioffi JA, Shafer AW, Zupancic TJ, Smith-Gbur J, Mikhail A, Platika D and Snodgrass HR: Novel B219/OB receptor isoforms: possible role of leptin in hematopoiesis and reproduction. Nat Med 2: 585-589, 1996.

17. Albertin G, Carraro G, Petrelli L, Guidolin D, Neri G and Nussdorfer GG: Endothelin-1 and adrenomedullin enhance the growth of human adrenocortical carcinoma-derived SW-13 cell line by stimulating proliferation and inhibiting apoptosis. Int $\mathbf{J}$ Mol Med 15: 469-474, 2005.

18. Albertin G, Carraro G and Nussdorfer GG: Human adrenomedullin gene silencing by short interfering RNAs: A preliminary study. Int J Mol Med 15: 579-583, 2005.

19. Rucinski M, Andreis PG, Ziolkowska A, Nussdorfer GG and Malendowicz LK: Differential expression and function of beacon in the rat adrenal cortex and medulla. Int J Mol Med 16: 35-40, 2005.
20. Mazzocchi G, Malendowicz LK, Ziolkowska A, Spinazzi R, Rebuffat P, Aragona F, Ferrazzi E, Parnigotto PP and Nussdorfer GG: Adrenomedullin (AM) and AM receptor type 2 expression is up-regulated in prostate carcinomas (PC), and AM stimulates in vitro growth of a PC-derived cell line by enhancing proliferation and decreasing apoptosis rates. Int J Oncol 25: 1781-1787, 2004.

21. Ziolkowska A, Rucinski M, Neri G, Di Liddo R, Nussdorfer GG and Malendowicz LK: Expression of the beacon gene in the rat adrenal gland: Direct inhibitory effect of beacon[47-73] on aldosterone secretion from dispersed adrenal zona glomerulosa cells. Int J Mol Med 13: 215-219, 2004.

22. Spinazzi R, Rucinski M, Neri G, Malendowicz LK and Nussdorfer GG: Preproorexin and orexin receptors are expressed in cortisol-secreting adrenocortical adenomas, and orexins stimulate in vitro cortisol secretion and growth of tumor cells. J Clin Endocrinol Metab 90: 3544-3549, 2005

23. Miskowiak B, Brelinska R, Kosowicz J, Konwerska A, Ziolkowska A, Belloni AS, Nussdorfer GG and Malendowicz LK: Pneumadin in the ventral prostate of rats during postnatal development: A radioimmunological and immunocytochemical study. Int J Mol Med 13: 801-803, 2004.

24. Belloni AS, Guidolin D, Ceretta S, Bova S and Nussdorfer GG: Acute effect of ischemia on adrenomedullin immunoreactivity in the rat heart: An immunocytochemical study. Int J Mol Med 14: 71-73, 2004

25. Camina JP, Lage M, Menendez C, Grana M, Garcia-Devesa J, Dieguez $\mathrm{C}$ and Casanueva FF: Evidence of free leptin in human seminal plasma. Endocrine 17: 169-174, 2002.

26. Frankenberry KA, Somasundar P, McFadden DW and Vona-Davis LC: Leptin induces cell migration and the expression of growth factors in human prostate cancer cells. Am J Surg 188: 560-565, 2004.

27. Ribeiro R, Lopes C and Medeiros R: Leptin and prostate: implications for cancer prevention. Overview of genetics and molecular interactions. Eur J Cancer Prev 13: 359-368, 2004.

28. Ribeiro R, Vasconcelos A, Costa S, Pinto D, Morais A, Oliveira J, Lobo F, Lopes C and Medeiros R: Overexpressing leptin genetic polymorphism $(-2548 \mathrm{G} / \mathrm{A})$ is associated with susceptibility to prostate cancer and risk of advanced disease. Prostate 59: 268-274, 2004

29. Bub JD, Miyazaki T and Iwamoto Y: Adiponectin as a growth inhibitor in prostate cancer cells. Biochem Biophys Res Commun 340: 1158-1166, 2006.

30. Baillargeon J and Rose DP: Obesity, adipokines, and prostate cancer (Review). Int J Oncol 28: 737-745, 2006.

31. Amling CL: Relationship between obesity and prostate cancer. Curr Opin Urol 15: 167-171, 2005.

32. Stattin P, Soderberg S, Hallmans G, Bylund A, Kaaks R, Stenman UH, Bergh A and Olsson T: Leptin is associated with increased prostate cancer risk: a nested case-referent study. J Clin Endocrinol Metab 86: 1341-1345, 2001.

33. Somasundar P, Frankenberry KA, Skinner H, Vedula G, McFadden DW, Riggs D, Jackson B, Vangilder R, Hileman SM and Vona-Davis LC: Prostate cancer cell proliferation is influenced by leptin. J Surg Res 118: 71-82, 2004.

34. Onuma M, Bub JD, Rummel TL and Iwamoto Y: Prostate cancer cell-adipocyte interaction. Leptin androgen-independent prostate cancer cell proliferation through c-Jun NH2-terminal kinase. J Biol Chem 278: 42660-42667, 2003. 